\title{
Notice of retraction
}

Zehra Aycan, Sinem Akgül, Selçuk Gençay, Nuray Kanbur and Orhan Derman

\section{Retraction of: Assessment of academic performance of licensed athletes}

https://doi.org/10.1515/ijamh-2020-2140

By this notice, the Editor and the Publisher of International Journal of Adolescent Medicine and Health retract from publication the following article at author's request: Zehra Aycan, Sinem Akgül, Selçuk Gençay, Nuray Kanbur, Orhan Derman, Assessment of academic performance of licensed athletes, IJAMH (2019), Ahead of Print, DOI https://doi.org/10. 1515/ijamh-2019-0184. This retraction is considered to be due to an honest error. The authors of the above mentioned article, Zehra Aycan, Sinem Akgül, Selçuk Gençay, Nuray Kanbur, Orhan Derman, credibly declares not having been aware of publication of the same work in Asia Pacific Journal of Pediatric and Child Health. Authors are deeply sorrowed and ask the readership to accept their sincere apologies. 